\title{
PENGARUH KONTAMINASI SALIVA TERHADAP KEKUATAN TARIK ANTARA RESIN KOMPOSIT DENGAN JARINGAN DENTIN
}

\author{
A.Soufyan, D.J. Indrani, M.Erlinda \\ Departemen Dental Material Fakultas Kedokteran Gigi Universitas Indonesia
}

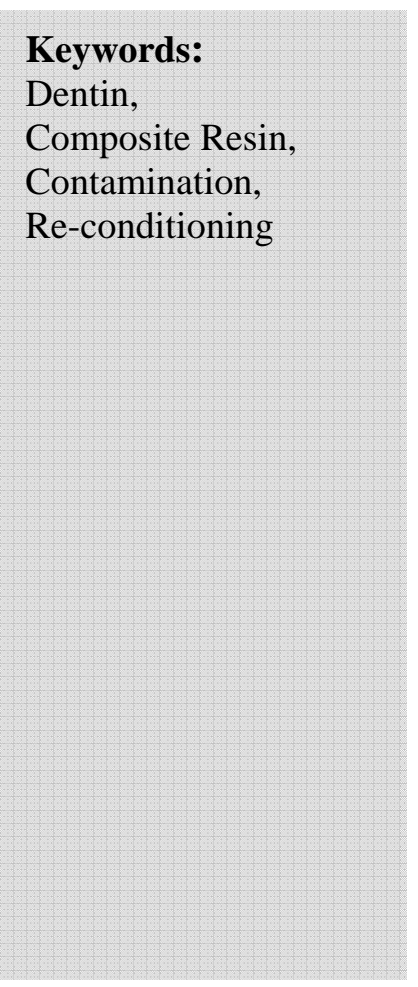

\begin{abstract}
Composite resin are restorative materials having color similar to teeth and have been widely used in dentistry. The successful application of composite resin influences the duration of the restoration in the oral cavity. The aim of this research is to describe the influence of artificial saliva contamination and the application of re-conditioning on tensile bond strength of composite resin to dentin. In the control group, the dentin were etched, bonding were applied and composite resin were restored on the dentin. In the group with artificial saliva contamination without re-conditioning, the dentin were etched, bonding were applied and then contaminated with artificial saliva, dried and then restired with composite resin. While the group with artificial saliva contamination with re-conditioning, the dentin were etched, bonding were applied and contaminated with artificial saliva, and then etched and applied bonding agent and restored composite resin.Bond strength test used "Universal testing machine, AG 5000. The results showed that highest value of tensile bond strength of composite resin to dentin was at the control group. It can be concluded that artificial saliva contamination decreased tensile bond strength while re-conditioning application increased it.
\end{abstract}

\section{Pendahuluan}

Resin komposit merupakan salah satu bahan restorasi sewarna gigi yang menjadi pilihan saat ini. Penggunaan resin komposit antara lain untuk tumpatan gigi anterior dan gigi posterior $^{1}$.

Kontaminasi saliva merupakan hal yang sering terjadi dalam aplikasi resin komposit. 
Berdasarkan penelitian dilaporkan bahwa antara resin komposit dengan struktur gigi tidak boleh terkontaminasi oleh cairan seperti saliva, darah, plasma, saline dan debri. ${ }^{2.3}$ Daerah yang terdekat dengan tepi ginggiva dan di tepi ginggiva itu sendiri mudah terkontaminasi saliva ataupun cairan sulkus ginggiva.

Dentin bonding system sangat sensitif terhadap saliva dan plasma. Pada email, reetching dengan asam fosfat dapat menghilangkan presipitat protein dari saliva. Pada pengetsaan dentin, asam fosfat dapat membuka tubuli dentin dan membersihkan peritubular yang terkontaminasi debris dari semen sementara. Pengaruh kontaminasi saliva terhadap dentin diteliti dengan mengukur kekuatan tarik antara komposit dengan jaringan dentin serta dengan observasi melalui scanning electron microscope. ${ }^{2.3}$.

Kontaminasi saliva membuat perlekatan antara tumpatan dengan jaringan dentin terganggu. Perlu diketahui adanya pengaruh kontaminasi saliva dan re-conditioning terhadap kekuatan tarik antara resin komposit dengan jaringan dentin. Berdasarkan hal tersebut di atas, maka dilakukan penelitian kekuatan tarik antara resin komposit dengan jaringan dentin yang terkontaminasi oleh saliva.

\section{Bahan dan Cara Kerja Persiapan spesimen}

Gigi sapi direndam dalam larutan $\mathrm{H}_{2} \mathrm{O}_{2}$ 3\% selama 7 hari, kemudian gigi dipotong di bagian servik dengan carborundum disc. Jaringan pulpa diambil dengan kawat baja tahan karat dengan diameter 0,7 mm, kemudian kamar pulpa di irigasi dengan larutan $\mathrm{NaOCl}$ $2,5 \%$. Gigi disimpan di dalam pot berisi aquadest dan diletakkan di dalam inkubator.

\section{Pembuatan spesimen}

Permukaan labial gigi diratakan dengan kertas silicon carbide no 400 sampai terlihat permukaan dentin, kemudian permukaan dentin dihaluskan dengan kertas silicon carbide no 600 menggunakan mesin poles Struers LaboPol-21. Permukaan dentin di bilas dengan aquadest dan dikeringkan dengan tekanan udara ringan menggunakan alat chip blower. Di atas permukaan dentin direkatkan PMMA ring (diameter bagian dalam $4 \mathrm{~mm}$, bagian luar 6 $\mathrm{mm}$ dan tebal $1 \mathrm{~mm}$ ) dengan bantuan double tape yang telah dilubangi seluas permukaan bagian dalam PMMA ring. Dentin di etsa memakai Gluma, Comfort Bond selama 30 detik, dibilas dengan aquadest dan dikeringkan dengan tekanan udara ringan. Dentin bonding agent (Gluma Comfort Bond Heraeus Kulzer) diaplikasikan dengan cara pengolesan sebanyak 3 kali dan didiamkan selama 15 detik, kemudian dikeringkan dengan tekanan udara ringan dan disinari dengan Light Curing Unit Dentamerica selama 20 detik. Aplikasikan resin komposit Solitaire 2, Heraeus Kulzer ke dalam PMMA ring kemudian disinari selama 40 detik. Di atas permukaan resin komposit direkatkan PMMA rod dengan diameter $10 \mathrm{~mm}$ dan tinggi $20 \mathrm{~mm}$ menggunakan perekat self cure acrylic merek vertex. Prosedur ini dilakukan untuk pembuatan spesimen kontrol.

Spesimen terkontaminasi dibuat tanpa reconditioning. Seperti pada prosedur pembuatan spesimen kontrol, setelah diolesi bonding agent, spesimen dan disinari. Spesimen di tetesi artifisial saliva dari formula Fusayama selama 60 detik. Spesimen dikeringkan dengan tekanan udara ringan, kemudian langsung diaplikasikan resin komposit dan disebabkan perekatan PMMA rod. Spesimen terkontaminasi dengan re-conditioning yaitu spesimen setelah terkontaminasi dilakukan re-conditioning dengan cara dilakukan etsa ulang dan pengolesan bonding agent seperti pada prosedur awal. Spesimen di uji tarik dengan alat uji Universal Testing Machine merek Shimadzu Autograph AG-5000 dengan beban maksimal $50 \mathrm{Kg}$ F dan kecepatan 0,5 mm/menit.

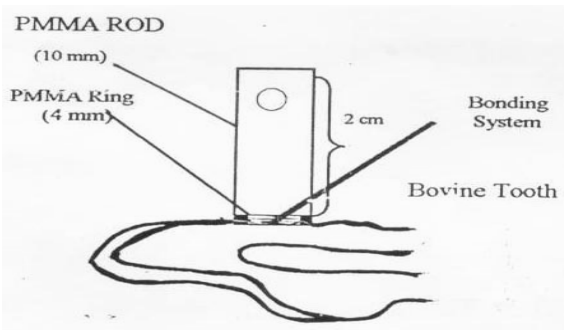

Gambar 1. Bentuk spesimen uji tarik 
Sumber : Dari A. Soufyan, B. Irawan, G. Gunadi, A. Noerdin. Pengaruh Berbagai Konditioner Dentin (Asam Phospat) Terhadap Kekuatan Tarik Antara Adhesive Resin (HNPM/TEGDMA) Dengan Jaringan Dentin, Jurnal Kedokteran Gigi Universitas Indonesia 2003:10;206-210

\section{Hasil penelitian}

Tabel 1. Kekuatan tarik antara resin komposit dengan jaringan dentin (MPa)

\begin{tabular}{|l|l|l|}
\hline Kontrol & $\begin{array}{l}\text { Terkontaminasi saliva } \\
\text { tanpa re-conditioning }\end{array}$ & $\begin{array}{l}\text { Terkontaminasi } \\
\text { saliva dengan } \\
\text { re-conditioning }\end{array}$ \\
\hline$\overline{\mathrm{X}}=10,081$ & $\overline{\mathrm{X}}=5,082$ & $\overline{\mathrm{X}}=8,972$ \\
$\mathrm{SD}=2,919$ & $\mathrm{SD}=1,334$ & $\mathrm{SD}=1,740$ \\
\hline $\mathrm{SE}=0,923$ & $\mathrm{SE}=0,422$ & $\mathrm{SE}=0,550$ \\
\hline
\end{tabular}

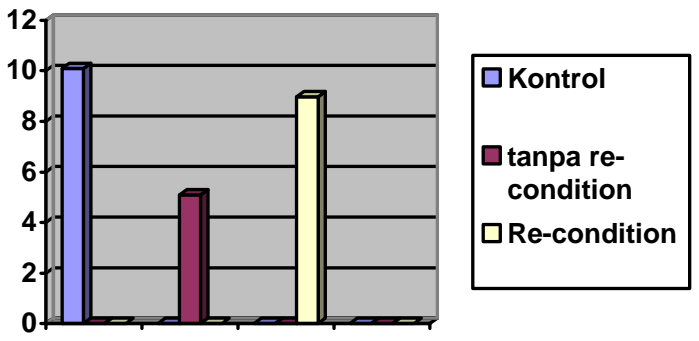

Gambar 1. Rerata kekuatan tarik antara resin komposit dengan jaringan dentin

Secara deskriptif tampak bahwa kelompok kontrol memiliki nilai rerata kekuatan tarik tertinggi yaitu 10,081 MPa, diikuti oleh kelompok terkontaminasi dengan reconditioning dengan nilai rerata kekuatan tarik 8,972 MPa. Nilai rerata terendah ada pada kelompok terkontaminasi tanpa re-conditioning yaitu 5,082 MPa. Hasil uji Paired samples 'T' test menunjukan perbedaan bermakna antara kelompok kontrol dengan kelompok terkontaminasi tanpa re-conditioning. Perlakuan kontaminasi menurunkan kekuatan tarik antara resin komposit dengan jaringan dentin. Pada kelompok yang dilakukan re-conditioning didapatkan nilai rerata lebih tinggi dibandingkan dengan kelompok tanpa re- conditioning. Perlakuan re-conditioning akan meningkatkan kekuatan tarik antara resin komposit dengan jaringan dentin. Secara statistik ditemukan perbedaan bermakna antara kelompok re-conditioning dan tanpa reconditioning. Sedangkan antara kelompok kontrol dan kelompok re-conditioning tidak ada perbedaan kekuatan tarik yang dihasilkan.

\section{Pembahasan}

Pada kelompok terkontaminasi saliva tanpa re-conditioning, nilai kekuatan tarik antara resin komposit dan jaringan dentin menurun. Hal ini dimungkinkan oleh masuknya komponen saliva seperti air dan protein $\mathrm{Ca}^{2+} \mathrm{ke}$ ruang nanometrik. Air akan berikatan hydrogen dengan serat kolagen sehingga terjadi ekpansi serat kolagen. Air tidak berikatan dengan bahan resin komposit yang bersifat hidropobik. Ruang interfibrillar, tubuli dentin, ruang antara peritubular dentin dengan serat kolagen akan terisi saliva sehingga mengganggu penetrasi resin. ${ }^{2.5}$ Lapisan air merupakan molekul tebal pada permukaan yang akan menghambat kontak adhered, yang akan menurunkan kekuatan ${ }^{5.7}$

Pada kelompok terkontaminasi saliva dengan re-conditioning, nilai rerata kekuatan tarik antara resin komposit dengan jaringan dentin lebih besar dibanding tanpa reconditioning. Prosedur pengetsaan akan melarutkan komponen saliva, mendemineralisasi dentins, membuka tubuli dentin yang telah terisi komponen saliva. Etsa juga akan meningkatkan kembali enerji permukaan dentin. Penetrasi materi adesif ke jaringan dentin menjadi lebih mudah karena tidak terhalang oleh komponen saliva. Proses pengeringan kontaminan dari saliva dengan tekanan udara ringan pada kenyataannya tidak menghilangkan seluruh komponen saliva, karena ada komponen yang terjebak di dalam ruang nanometrik. Namun Re-conditioning itu sendiri mempersiapkan kembali jaringan dentin untuk menerima penetrasi materi adesif ${ }^{5.6 .8}$ 


\section{Kesimpulan}

Hasil penelitian ini menggambarkan bahwa kekuatan tarik antara resin komposit dengan jaringan dentin akan memperoleh nilai kekuatan tarik yang optimal pada kelompok kontrol karena tidak ada kontaminan yang mengganggu. Prosedur re-conditioning efektif untuk meningkatkan kembali kekuatan tarik antara resin komposit dengan jaringan dentin. Selama prosedur aplikasi resin komposit di dalam rongga mulut harus dihindari terjadinya kontaminasi oleh saliva, maupun cairan yang berasal dari debris.

\section{Daftar Pustaka}

1. Baum, Phillips, Lund. (1997). Buku Ajar Ilmu Konservasi Gigi. Ed.3 Jakarta: EGC

2. Hiraishi N, et al. Effect of Artificial saliva Contamination on $\mathrm{PH}$ value change and Dentin bond strength. Journals Dental Materials, 2003; 19 : 429-34.

3. IH eL-Kaa-lla, Saliva contamination and resin micromorpological adaptation to cavity walls using sigle bottle adhesives.Am J Dent.1999 Aug12 (4); $172-6$

4. Soufyan, B. Irawan, G. Gunadi, A. Noerdin. Pengaruh Berbagai conditioner Dentin (asam Phospat) Terhadap kekuatan Tarik antara Ahesive Resin (HNPM/TEGDMA) Dengan jaringan Dentin. Jurnal Kedokteran Gigi Universitas Indonesia 2003: 10; 206-10

5. Pashley DH, Nelson AR, Kepler E.E. The Effects of Plasma and Salivary Constituents on Dentin Permeability. J.Dent Res. 1982 - 61 (8): 978-81.

6. Loper G.C, et al. Dental Adhesion: Present State of the art and Future perspectives. Quintessence Int. 2002; 33: 312-24.

7. O’ Brien William J (1997). Dental Materials and their Selection $2^{\text {nd }}$ ed. U S A : Quintessence Publishing Co. Inc. pp. 100-106.

8. Nakabayashi.N, Pashley D H. Hybridization of Dental Hard Tissue. Tokyo : Quintessence Publishing Co, Ltd.1998. 
Data Penulis

Nama : drg Andi Soufyan Santosa M.Kes

Alamat : Jl. Rohto No 16 Kimia Farma II Duren Sawit

Jakarta Timur 13440

Telp : $0218625220 / 08121837534$

Instansi : Departemen Ilmu Material Kedokteran Gigi

Fakultas Kedokteran Gigi

Universitas Indonesia 